\title{
TRANSLATION PROJECT AS AN ASSESSMENT TOOL: UKRAINIAN CONTEXT
}

\author{
Tetiana Korol \\ Kyiv National Linguistic University, Kyiv, Ukraine \\ E-Mail: koroltatyanalq@gmail.com
}

\begin{abstract}
The given paper focuses on the analysis of a translation project as a powerful assessment tool that can be easily integrated into prospective philologists' university training in order to enhance its quality and bring its outcomes into line with global industrial needs and requirements. With this aim, substantial translation pedagogy experience of project-based learning is consolidated from the viewpoint of action-oriented, student-centered, situated, experiential and reflective approaches. Translation project properties, design features, role and function distribution peculiarities typical for global professional environment are considered. The received findings are transferred and adjusted to the current terms and conditions of prospective philologists' training in Ukrainian higher educational setting. As a result, a working classification of translation project varieties to be developed and implemented into training process at different training stages is suggested. Their functions and potential usage as a flexible assessment framework is specified. The translation project opportunity for the arrangement of not only formative but summative assessment as well is substantiated due to its contrasting to the existing examination practices. Finally, the idea of cross-assessment as the complex assessment procedure conducted from different perspectives (hetero, self- and peerassessment) with the help of versatile tools and instruments (incorporated into single flexible translation project) is introduced.
\end{abstract}

Key words: translation project, self- and peer-assessment, formative and summative assessment, cross-assessment

\section{INTRODUCTION}

Rapidly expanding translation industry attracts more and more employees all over the globe. According to different sources jobs in this sector are expected to grow about $18 \%$ during the current decade. This forecast is accompanied with obvious market share increase, greater competition, emergence of new professions and fields, higher industrial standards and requirements. While language service providers are constantly pointing to the gap between current market needs and graduates' actual translation competence level. The latter factors combined with general demographic trend to have better command of foreign languages, English in particular, which widens its scope to the ability to mediate in bilingual communication, stipulated by CEFR requirements (Common European Framework of Reference for Languages: Learning, Teaching, Assessment. Companion Volume with 
Descriptors, 2018), urge tertiary institutions all over the world to provide prospective philologists and translators with better training opportunities.

In Ukrainian context high demand for translation services has been reported to lead to a booming number of the establishments of higher education offering Bachelor's and Master's degree programs in Philology. According to the internet resource education.ua their number equaled 117 in 2018, while Philology took the third place in the most popular specialty rating among school-leavers. It should be noted here that since 2015 translation and interpretation services in Ukraine should be provided by Philology graduates due to the changes in the National Classification of Occupations. To our mind such reform to some extent contradicts translation industry mainstream which requires skilled either translators or interpreters with relevant translation and interpretation skills and abilities, profound erudition and field specific background knowledge, creative and analytical thinking, ability to use CAT tools and work both individually and in a team, self-educate and respond flexibly to ongoing market changes. So under current conditions the provision of high standard prospective translators' training in Ukraine appears to be highly challenging.

These factors encourage both scientists and practitioners to develop and apply new approaches to the improvement and assistance in the prospective philologists' training in Ukrainian context. A special role in this search belongs to the substantiation and elaboration of the efficient assessment system consolidating external industrial requests and internal training conditions. In modern higher educational setting the efficient assessment system should cooperate closely with the training process providing not only timely feedback and evaluation of learning outcomes but facilitating knowledge acquisition, skills and competence formation, forecasting graduates' performance under conditions of professional environment in the nearest future. Such approach to assessment in prospective philologists' training causes the need for the involvement of multifunctional assessment tools and instruments. They should be flexible and versatile, practical from the viewpoint of development and processing of the obtained results, targeted to the evaluation of translation skills and abilities, in particular, and translation competence in general, reproduce real-life professional situations, eliminate students' stress and anxiety, motivate them and get involved into training and translating.

Taking into account all the above-listed needs we would like to suggest the development and usage of a translation project as quite a promising assessment tool. Over different names mainly explained with its dominating function or teaching strategy applied, e.g. experiential, collaborative translation project, etc., it has been studied in line with different approaches, i.e. action-oriented (D. Gile, 1994; D. Kiraly, 2005; S. Hubsher-Davidson, 2008), experiential (H. Risku, 2010; D. Kiraly, 2012), situated (M. Gonźalez-Davies, 2004; D. Kiraly, 2005; H. Risku, 2016), student-centered (D. Kiraly, 2005; J. Varney, 2009).

The design and components of the translation project were described by M. González Davies (2004) and D. Kelly (2005). The participant roles and their distribution in the authentic translation project were studied by S. Maruenda-Bataller and J. Santaemilia-Ruiz (2016). A project-based syllabus design was suggested by R. E. H. Mitchell-Schuitevoerder (2014). Even MNH-TT collaborative platform for translator training was developed (B. Babych, T. Hartley, K. Kageura, M. Thomas, M. Utiyama, 2012).

The translation project application for training students in different fields was also examined: business translation in Chinese educational setting (J. Zheng, 2017), technical translation (A. Galán-Maňas, 2011), subtitling (L. Istiqomah, 2018; I. A. Nagovitsyna and I. A. Lekomtseva, 2017), computer-assisted translation and localization (F. Mileto and 
L. Muzii, 2010) and even interpretation (E. R. Porshneva and Yu. O. Papilova, 2018). Students' opinions on translation project impact on their training outcomes (D. Li, Ch. Zhang and Yu.He, 2015) and feedback flow circulation in the authentic translation project (G. Massey and B. Braendli, 2014) were also reviewed. In most cases the mentioned authors reported on the results of single translation project completion, while it is still not clear how to use it in consistent way for regular training of prospective translators. Moreover, the given studies dealt with Master's degree students only, while no information was found if it is applicable and appropriate for other undergraduates. Anyway, notwithstanding its active and always successful use for different training purposes translation project has not been considered in terms of assessment function yet.

That is why the given paper is aimed at the analysis of the translation project as an assessment tool designed for the enhancement of prospective philologists' training process in general and upgrading of formative and summative assessment procedures in Ukrainian establishments of higher education in particular.

\section{TRANSLATION PROJECT: LINKING THEORETICAL APPROACHES AND PRACTICE TOGETHER}

According to H. Risku (2016) modern translation pedagogy is steadily moving to the implementation of student-centred, situated and experience-based training practices supported by social constructivist and participatory philosophy. In our research we will attempt to prove that they can be efficiently combined in practice with the help of the translation project aimed at the improvement of current assessment procedures in tertiary institutions.

\subsection{Experience-based Approach}

Experience-based or experiential approach to teaching and learning is aimed at the introducing students to real-life professional practices directly in the educational setting stimulating their learner autonomy and self-educational abilities, developing critical, analytical, creative, research, interpersonal and collaborative skills (D. Kiraly, 2005; S. Maruenda-Bataller and J. Santaemilia-Ruiz, 2016, p. 209), sought so much by industry employers in contemporary university graduates. A translation project as a specific type of mostly collaborative activity directed to the provision of language services presented for completion under university training conditions is able to involve students into real-life professional practice and provide them with the opportunity to test and improve their knowledge, skills and abilities solving translation problems in full-scale professional activity. According to the constructivist paradigm translation skills as some kind of automated abilities to perform specific type of cognitive and communicative activity should be developed and assessed through action only (G. Massey and B. Braendli, 2014). These ideas strongly correlate with action-oriented and problem-based approaches and correspond to the nature of translators' work that is never routine or repetitive.

\subsection{Collaborative Approach}

Within real-life translation projects professionals deal with all kinds of partners engaged into the event, collaborating with them in order to achieve their common goal producing translation product that is accepted or even appraised. In case of collaborative 
training due to real interaction students get use of shared experience rather than from knowledge transmitted by a teacher. It strongly correlates with the provisions of experiential approach and promotes the development of students' interpersonal skills and abilities to serve as a team member. In other words, it means to be able to assist and ask for help when necessary, provide objective comment and evaluation in the translation process, correct others and be ready to accept adequate critique. In terms of assessment it converts into strong peerassessment skills and strategies valuable for both future professional activity and current training process.

\subsection{Student-centered Approach}

Translation projects applied in educational settings are always student-centered and friendly. On the one hand, they strengthen trainees' responsibility, autonomy, confidence and positive self-efficacy, encourage self-regulation, critical reflective mechanisms and strategies, provide and maintain positive internal motivation to perform translation assignment in line with the translation brief requirements (D. Kiraly, 2005). On the other hand, translation project supports the idea of students' learning style diversity as a factor strongly affecting their current training and future professional activities. Being widely studied in other educational settings (O. Synekop, 2018), with the help of translation project it can be easily adapted to translation pedagogy needs. In case of assessment it gives the opportunity to implement dynamic assessment practice based on the social constructivist concept by L. Vygotsky.

\subsection{Situated Approach}

Translation is always performed by complex systems, involving human and IT resources, social and physical setting, cultural specific context, so it can be treated as a pattern of situated cognition and problem-solving (H. Risku, 2016). Let us consider the main principles of situated learning (H. Risku, 2016) in terms of a translation project as an assessment tool:

- collaboration: translation project is usually collaborative, even if not, it requires some interaction with a client or teacher. In the first case interpersonal abilities are measured and peer-assessment strategies are activated, while in the second hetero assessment results and feedback are received;

- construction: students formulate their own ideas solving translation problems and reconstruct the content of the original message with the means of target language during translation project;

- self-organization (new knowledge is always based on that prior acquired): translation project application to the training process should be based on students' previous experience of similar, even simpler translation assignments. It looks like the first translation brief can hardly be graded by the teacher;

- application in a social action context: translation products are not prepared in real-life just because the teacher asked, they are performed to be published and used. Here we can predict some kind of difficulties that should be considered later;

- use of shared artefacts: translation decisions are discussed, assessed, taken together and consistently used by all the team members during the project;

- feedback: every stage of the project should be commented on and assessed by all the participants in different forms that is perfect for objective assessment and grading;

- reflection: self-analysis and self-assessment are part and parcel of any activity, especially in case of translation. Projects always urge students to reflect on the translation process that is valuable for formative assessment procedures. 
Translation project precisely mirrors real-life professional situations, eliciting and preserving students' actions and behavioral patterns free from examination anxiety and stress. As a result, the teacher is able to receive intact and objective results close to their real-life possible performance at the given moment.

Situated approach is also valuable from the perspectives of consideration and elimination of particular translation problems connected with specific field or topic (lack of equivalent in English Ukrainian financial and technical terms, for instance, or relevant specific knowledge), language pairs (e.g. Russian-Ukrainian negative transfer in case of English to Ukrainian translation), real-life translation challenges which do not emerge in case of sentence by sentence translation in class. However, the above-mentioned factors still have strong impact on students' assessment results and real translation performance causing the main portion of students' translation mistakes and errors.

As we can see, translation project is consistent with all the requirements and provisions of the mainstream translation pedagogy approaches, which are often overlapping and intersecting. On the basis of the conducted analysis we consider experiential and situated ones to be mainly dominant in philologists' training context, while some provisions of reflective and transdisciplinary ones are also noticeable, being important from the point of view of translation assessment in general and specialized translation in particular.

\section{Translation Project Design as the Reflection of Professional ACtivity}

\subsection{What Makes up a Translation Project?}

Translation project implementation into students' training practice follows the concept of 'learning by doing' and 'assessing through doing', where students both gain and apply their knowledge and skills by working in small groups for some period of time to explore and solve real-life translation problems and challenges of transdisciplinary nature. As it has been shown above real-life professional situation is the key to success both in prospective philologists' training and its outcome assessment. In case of translation project it is reproduced due to (M. Gonźalez-Davies, 2004, p. 216-224):

- the presentation of authentic or relatively authentic translation assignments. They are closely connected with various factors such as type of translation being trained and assessed, target audience requirements and expectations, source text selected for translation and strongly depend on the training stage and students' translation skills.

- clear division and distribution of roles and responsibilities. Different researches single out different number of participants essential for the translation project performance and assign them versatile functions and responsibilities. So this important aspect will be commented on further.

- translation brief usage. A translation brief as a set of guidelines for translation performance is not always provided by the client even in real professional situation, but prospective philologist should be able either to use it or to prepare on the basis of the given translation assignment only. To our mind, for small translation projects it should be drafted by the teacher and presented to an individual or a team, while for long-term and large-scale projects this responsibility can be easily delegated to the project manager. Anyway, it will serve for project indirect managing, eliminating or assisting in tackling translation and other contiguous problems, setting product quality assessment criteria. 
- deadlines. In modern real-life situations they are crucial according to the main translation industry trends of 2018: customers are interested in speed first of all. In case of assessment, timely translation project presentation should be also very important, otherwise the translation team should be penalized as it happens in real professional environment. In terms of situated approach students must be responsible for every stage of the performed project and its quality product as well.

- incentives. Even authentic translation projects performed by students are not paid. But some kind of positive motivation apart from professional development should be invented by the teacher bearing in mind students strengths and weaknesses, interests and individual peculiarities and trying to avoid achievement motivation caused by grading and assessment effect.

- publication and dissemination of the target text. In case of authentic translation project completed in educational environment this item is obviously and easily performed: the requestors get their target text, use it according to their needs and even provide some feedback to the translation team. The situation is more complicated in case of relatively authentic translation projects (under which we mean already performed nonconfidential projects used for training and assessment goal only) and modelled translation projects prepared by the teacher. The alternative way out is seen in publishing the produced target texts on the Internet, where they are accessible to the general audience.

\subsection{Who Puts it into Effect?}

In our research we decided to adopt role distribution scheme proposed by S. MaruendaBataller and J. Santaemilia-Ruiz (2016) as the most suitable for our educational setting and requiring the least changes. All in all, they single out five different roles in translation project, namely:

- project manager,

- translator,

- terminologist,

- documentation specialist,

- editor or corrector.

While the other researchers (e.g. G. Massey and B. Braendli (2015)) suggest to appoint or elect besides a project manager a deputy one, translation memory trouble-shooter instead of documentation specialist (maybe because of obligatory involvement of CAT tools into their project) and students responsible for quality assurance during final revision phase instead of editor or corrector and students who will ensure the appropriate target text layout at the end of the project and present it to the client / teacher. In some scenarios clients can be also involved either this role is attributed to the teacher especially in case of relatively authentic and teacher-modelled translation projects.

To our mind, in some cases teacher can also participate under the same terms and conditions in the translation project with the students. The translation project may also involve some specialist experts from relevant fields as it often happens in real-life situations or this role may replace documentation specialist. Everything depends on the translation project aim and source text peculiarities.

Teams and roles can be formed and given by the teacher, acquired on voluntary basis or by loting as well. But still it should be noted here that we insist on the performance of particular portions of translation task by all the team members in spite of their additional 
responsibilities. It is also important to ensure the obligatory role interchange of students in different projects. From this point of view a team of four students is considered to be perfect: each member serves as a translator and additionally performs one more role.

The responsibilities of every role in the translation team are presented in Table 1 (summarized from S. Maruenda-Bataller and J. Santaemilia-Ruiz (2016)).

Table 1 Roles and responsibilities in a translation team

\begin{tabular}{|c|c|}
\hline Team role & Responsibilities involved \\
\hline Project manager & $\begin{array}{l}\text { - coordinate translation-oriented source text analysis } \\
\text { - } \text { ensure efficient work of the team } \\
\text { - draft translation brief if necessary } \\
\text { - } \text { set objectives } \\
\text { - coordinate all the stages of the project } \\
\text { - } \text { monitor team performance } \\
\text { - set schedules and mid-project deadlines } \\
\text { - contact with clients } \\
\text { - } \text { assess the quality of the documents involved } \\
\text { - } \text { present the final product } \\
\text { - prepare a project report }\end{array}$ \\
\hline $\begin{array}{l}\text { Documentation } \\
\text { specialist }\end{array}$ & $\begin{array}{l}\text { - } \text { participate in translation-oriented source text analysis } \\
\text { - search documentation to assist translation } \\
\text { - } \text { contact with other team members } \\
\text { - select comparable texts, similar to the source text or of the same type } \\
\text { - choose paper and electronic resources useful for translation problem solving } \\
\text { - compile project archives, reference list, etc. }\end{array}$ \\
\hline Terminologist & $\begin{array}{l}\text { - participate in translation-oriented source text analysis } \\
\text { - prepare vocabularies } \\
\text { - compile glossaries } \\
\text { - search proper equivalents } \\
\end{array}$ \\
\hline Translator & $\begin{array}{l}\text { - participate in translation-oriented source text analysis } \\
\text { - determine possible translation problems and difficulties } \\
\text { - study comparable and auxiliary texts } \\
\text { - list resources necessary for translation } \\
\text { - translate determined text fragment }\end{array}$ \\
\hline Editor /Revisor & $\begin{array}{l}\text { - participate in translation-oriented source text analysis } \\
\text { - study or create style guide } \\
\text { - revise text from the viewpoint of terminology used, style, structure, } \\
\text { content rendition completeness, clarity } \\
\text { - compare source and target text } \\
\text { - deliver final format to project manager }\end{array}$ \\
\hline
\end{tabular}

\subsection{What forms can it take?}

Taking into account such nine criteria as assessment type provision, authenticity level, translation assignment scope, number of participants, duration, place of completion, teacher 
involvement, CAT tools involvement, level of students' autonomy we have developed working translation project classification, presented in Table 2.

Table 2 Translation project classification

\begin{tabular}{|c|c|}
\hline Criterion & Translation project type \\
\hline $\begin{array}{l}\text { Assessment type } \\
\text { provision }\end{array}$ & $\begin{array}{l}\text { - } \text { formative } \\
\text { - } \text { summative }\end{array}$ \\
\hline Authenticity level & $\begin{array}{l}\text { - } \text { completely authentic } \\
\text { - relatively authentic } \\
\text { - teacher-modelled }\end{array}$ \\
\hline $\begin{array}{l}\text { Translation } \\
\text { assignment scope }\end{array}$ & $\begin{array}{l}\text { - full cycle } \\
\text { - fragmentary / task-based }\end{array}$ \\
\hline $\begin{array}{l}\text { Number of } \\
\text { participants }\end{array}$ & $\begin{array}{l}\text { - } \text { individual } \\
\text { - } \text { pair } \\
\text { - } 3 \text { members } \\
\text { - } 4 \text { members } \\
\text { - } \text { student academic group }\end{array}$ \\
\hline Duration & $\begin{array}{l}\text { - } \text { short-term (about a week) } \\
\text { - } \text { medium-term ( } 2-3 \text { weeks }) \\
\text { - } \text { long-term (4-6 weeks) } \\
\end{array}$ \\
\hline $\begin{array}{l}\text { Place of } \\
\text { completion }\end{array}$ & $\begin{array}{l}\text { - in class } \\
\text { - } \text { combined } \\
\text { - } \text { out of class } \\
\end{array}$ \\
\hline $\begin{array}{l}\text { Teacher } \\
\text { involvement }\end{array}$ & $\begin{array}{l}\text { - minimal (as a consultant, for completely authentic projects) } \\
\text { - medium (as a client) } \\
\text { - overall (as a team member) }\end{array}$ \\
\hline $\begin{array}{l}\text { CAT tools } \\
\text { involvement }\end{array}$ & $\begin{array}{l}\text { - } \text { without CATs } \\
\text { - CAT-based }\end{array}$ \\
\hline $\begin{array}{l}\text { Level of students' } \\
\text { autonomy }\end{array}$ & $\begin{array}{ll}\text { - } & \text { full } \\
\text { - } & \text { partial } \\
\end{array}$ \\
\hline
\end{tabular}

It is clear that the distinguished translation project types can be combined in different ways according to teacher's and assessment needs.

\section{TRANSLATION PRoJECT AS A CROSS-ASSESSMENT TOOL}

The idea of the efficient assessment is very simple here: the way we train, the way we control and assess. It is impossible to practice 'chalk and talk' or WTNS (Who'll take the next sentence?) (D. Kiraly, 2012) in class and set a translation problem to be solved in a test. And quite contrary, if we train by doing, we are to assess by doing too. In order to use a translation project for assessment objectives we are to provide our students with some previous experience of performing similar assignments or their fragments at least using appropriate types of translation projects.

In general, as an assessment tool translation project complies with the main requirements essential for translation training environment and Ukrainian higher educational setting. It ensures assessment regularity (correspondence of training stages with relevant assessment types) in general, and facilitates monitoring and formative assessment paying special 
attention to the assessment objects in particular. Translation project provides opportunities for individualization and personalization of assessment, forms students' positive motivation modelling real-life professional situations. Translation project provides opportunities for both formative and summative assessment in contrast to traditional examinations lacking professional authenticity. Translation project due to its nature allows to combine efficiently the procedures of hetero, self- and peer-assessment. They can be applied for the evaluation of two main indicators of students' translation competence level such as translation process and translation product. In such a way cross-assessment as the complex assessment procedure carried out from different perspectives with the help of diversified tools and instruments can be introduced into the training process.

\section{CONCLUSION}

On the basis of the conducted research we have proved the appropriateness of translation project application to the assessment of prospective philologists' translation competence in the context of Ukrainian establishments of higher education. On the one hand, it entails all the provisions of the leading approaches to modern translation pedagogy, such as experiential and situated, while on the other, it correlates with the requirements set by Ukrainian educational setting. The analysis of the translation project structural peculiarities, roles and functions allowed suggesting working classification of assessment translation projects based on nine criteria. Finally, translation project is considered to be a versatile framework for crossassessment realization, which can be easily adjusted to the needs of the training process and its subjects.

\section{REFERENCES}

Kiraly, Don. 2005. «Project-Based Learning: A Case for Situated Translation». Meta, 50(4):1098-1111. https://doi.org/10.7202/012063ar.

Kiraly, Don. 2012. «Growing a Project-Based Translation Pedagogy: A Fractal Perspective». Meta, 57(1):82-95. https://doi.org/10.7202/101274ar.

Risku, Hanna. 2016. «Situated Learning in translation Research Training: Research as a Reflection of Practice». The Translator and Interpreter Trainer (ITT),10(2): 12-28. https://www.ncbi.nlm.nih.gov/pmc/articles/PMC4959122/

Synekop, Oksana. 2018. «Cognitive Aspect of Learning Style in Differentiated ESP Instruction for the Future IT Specialists». Advanced Education, 10:40-47. https://doi.org/10.20535/2410-8286.151271.

González Davies, Maria. 2004. Multiple Voices in the Translation Classroom. Activities, Tasks and Projects. Amsterdam/Philadelphia: John Benjamins.

Maruenda-Bataller, Sergio, and Jose Santaemilia-Ruiz, J. 2016. «Project-Based Learning and Competence Assessment in Translation Training». In Technology Implementation in Second Language Teaching and Translation Studies, New Frontiers in Translation Studies, edited by Carrió-Pastor, 207-228. Singapore: Springer Science+Business Media.

Massey, Garry, and Barbara Braendli. 2015. «Collaborative feedback flows and how we can learn from them». In Investigating a synergetic learning experience in translator education, edited by Don Kiraly,177-199. Mainz University Press: V\&R unipress. 